\title{
Impact Analysis of Covid19 on Secondary Sector of Indian Economy: A Meta-Analysis of Textile Apparel and Automobile Sectors
}

\author{
Monirul Islam
}

Xavier Business School (XBS), St Xavier's University, Kolkata, West Bengal, India.

\begin{abstract}
This research paper focused on analysing the results of previous studies conducted by different researchers to examine the impact of Covid19 on the Secondary sector of Indian economy over the selected sectors of Textile and apparel ( $\mathrm{T} \& \mathrm{~A}$ ) and Automobile Components respectively. The whole world is in the grasp of Coronavirus. The diffusion of the virus is so immense that it obliged the World Health Organisation to declare it as a pandemic. The severe outbreak of the virus has unparalleled implications on the worldwide economy. Unembellished economic onus and grave aftermath shock have been borne by almost all sectors Indian economy. Meanwhile, the industries in this framework of nose diving economic situation are due to the pandemic. Therefore, this article is intended to study the impacts of Covid19 on secondary sectors of Indian economy. This study would also explore the impact of Pandemic as an independent variable and the resultant effect in terms of sectorial impact as a dependent variable.
\end{abstract}

Keywords: Covid19, Pandemic, Indian Economy, secondary sector.

\section{INTRODUCTION}

Economically speaking, India is confronted today with conceivably its paramount emergency post- Independence. The analysis of Impact of COVID-19 on varied sectors of Asian nation is a war with Associate in nursing invisible enemy. The virus that started within the urban centre of China has affected virtually each a part of the globe and is considered one among the worst times in human history. The major Indian economic sectors, as well as China, the USA, Asian Nation and plenty of European nations (EU), area unit subject to total or partial closure. The epidemic has caused turmoil and has a substantial impact on the individuals and the economy of previous mentioned countries. It's impact can be depicted from Figure1

For the past few months, what Asian nation and the world have seen is impossible. We've got been concerned in several discussions on what has been happening. However, from Associate in nursing economic posture, a serious concern is that the way forward for the assorted industries in Asian nation. At the same time, lockdown measures such as social distancing is have a direct impact on people's mental health.

*Address of Correspondence: Dr. Monirul Islam, Assistant Professor of Marketing Management, Xavier Business School (XBS), St Xavier's University, Kolkata, West Bengal, India, India.

E-mail-moni05081985@gmail.com

(Received 20 December 2020; Revised 25 January 2021; Published Online 31 January 2021) 
This is a marathon, not a sprint and the times ahead will present endless leadership moments and difficult decisions.

\section{PURPOSE OF THE STUDY}

1. To highlight the impact of coronavirus on the secondary sectors of the Indian economy.
2. To specifically assess the impact of pandemic on Textile and apparel (T \& A) sector.

3. To specifically analyse the impact of pandemic on Automobile sectors.

4. To advise business strategies that the sectors should adopt in order to survive this threatening situation.

\section{The impact of corona virus lockdown on India's migrant population}

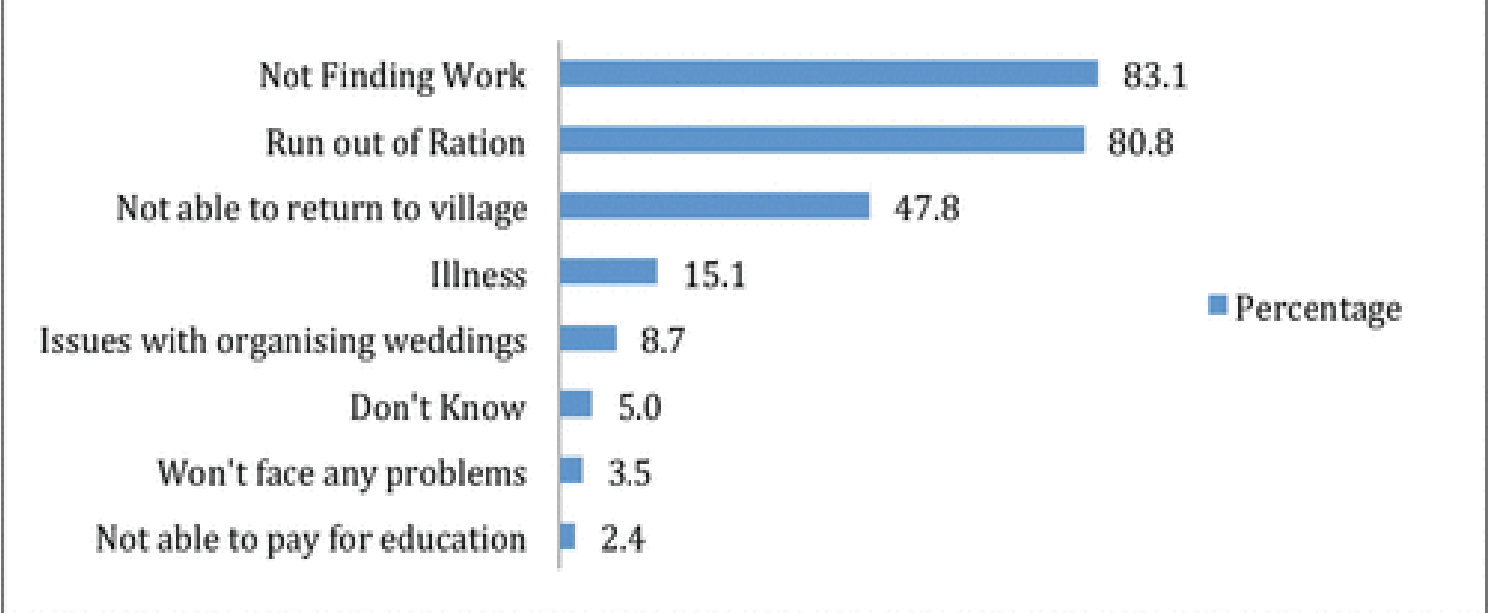

Figure 1: Impact of COVID-19 on Migrant Population

Source: Jan Saahas Survey (2020).

\section{Theoretical approach}

The global financial catastrophe in 2008-09 was a colossal demand shock, but our workforces could still go to work, our businesses were coming off years of strong progression. Also, our monetary system was fundamentally sound, and our government capitals were in good physical shape. None of this holds true today as we combat the coronavirus pandemic. Covid-19 pandemic has obstructed our lives, behaviours and habits. Industries are correspondingly impacted given the volatility, disruptions, uncertainties, complexities, ambiguities and changes in the consumer's mind set.

\section{METHODOLOGY}

A positivist theory, a deductive approach and a quantitative method accompanied by surveybased study design are employed in the research methodology. 
FINDINGS AND ANALYSIS

\section{Apparel and Textile business}

The Indian Textiles and Apparels (T\&A) business accounts for regarding fourdimensional of the world T\&A market. The T\&A sector is one among most significant the biggest and most important sectors of the Indian economy in terms of outcomes, exchange profits and employment. The business contributes regarding seven-membered to industrial output in terms important, a pair of to gross domestic product and V-J Day to export earnings.

Because of Covid19 there could be a 1 crore job cuts in textile industry in India without any government support (CMAI). Around 80 percent of the Indian garment industry is micro, small and medium enterprises (MSME) where more than 3700 members are helping to get employed 7 lakh people (CMAI). And they do not even have any backup plan to sustain for upcoming months without the job because they are the daily wage earners (1).

Indian Textiles and Apparels industry which is approximately 4 per cent of the global Textiles and Apparels market and the industry is one of the largest and the most important sectors for the Indian economy. And in terms of output, foreign exchange earnings and employment which make this industry contribution approximately seven per cent output in terms of value, $2 \%$ to the GDP and $15 \%$ to the India's export earnings. (CMIE report)

The Indian economy has been hit arduous by COVID-19. Thanks to the closure of the area unit the world the realm varied transit facilities as well as rail and airports are suspended that are expected to break domestic operations in Asian nation.

It is imperative that the Covid19 pandemic has created a fuss amongst various nations worldwide and brought them under lockdown. This lockdown has disturbed people, places, industries, markets etc. The irreparable damage caused due to this crisis has also impacted the Apparel and textile industry in the subsequent ranges:

Employment: The worldwide shut has worst affected upon employment. The T\&A industry being largest in the country provide jobs to a million Indians. These employed people lost their livelihoods once the lockdown was imposed. The closed factories, layouts, shops etc. deployed unemployment to various citizens. About more than 45 million people lost their jobs amidst lockdown in this industry.

Imports and exports: The worldwide lockdown have impacted the import and exports of raw materials and readymade garments. Exports have been lowered due to which even the domestic markets have suffered. The country's export earnings have come down drastically due to cease in orders worldwide. New stores and factory setup must halt due to all India closure.

\section{Supply chain disruptions: Due to} disruption in supply chains, the products are unable to reach the end consumers. This has led to huge stocks in the factories. Hence, local sourcing needs to be implemented. Garment makers ought to scrutinize the chances of locating, the right impact on imports and exports (2). 


\section{- Labour force and employment:}

T\&A provide direct employment to over fortyfive million individuals however movement down nationwide has crystal rectifier to temporary closure of factories and job losses have begun among the low wage staff.

\section{- Import \& Exports of staple and} readymade garment: The COVID-19 epidemic is predicted to possess a negative impact on exports and the impact of the second order on domestic markets with all sales and residential sales falling. If the world closure continues and the scenario persists, it will affect the buyer sentiment on the high aspect, thanks to the closure of the market and supermarkets yet as maintaining social isolation, safety and health.

- Consumer sentiment: All the above factors have huge impact on the sentiments of consumers. We may also expect slow recovery in the aftermath. Government needs to aid the people and their families stuck in the verge of lockdown due to unemployment and consumer sentiments needs to be protected.

\section{- Cash flow constraints: The arena} was still fighting profit thanks to a pointy call exports, cheaper costs etc. These problems look to still step up over the present crisis.

The epidemic has affected most of the Indian export market (US and EU combined structure regarding $\mathrm{hr}$ of India's exports), inflicting cancellation / cargo ends up in slow inventory and anticipation of slow understanding of export receipts resulting in high performance needs of upper worth.
Shipments of article of clothing area unit expected to say no thanks to orders being suspended within the half-moon of FY20, operational money problems and a scarcity of clarity of activities and interests particularly exporters from Asian nation and Vietnam receive special access. In addition, domestic consumption is additionally affected thanks to the remainder of India's closure. New store openings are halted and even domestic stores face construction problems as the sources of article of clothing for the forthcoming season, what is more, home costs may be adversely affected if speculators throw their belongings into the house market leading up to weddings. This may cause shorter periods like reduced temporary employment (factory closures and other people returning to their hometowns) and reduced outlay. The aftermath impact anticipates being as follows: -

The length of the nationwide internment can directly influence the length of the recovery cycle. However, reducing the burden, Confederation of Indian Textile business (CITI) has known as on the government to instantly announce a package of help to the textile and garment industries to alleviate the distress facing the textile business.

The overall demand of textile items abroad and local deals have boiled down to a crushing end because of the frenzy circumstance made by the COVID 19 spread. Labourers have been running to a great extent during a wide range of disarray. The business network is frightened because of money crunch, flexibly chain unsettling influence and labour related issues. 
Clothing exports are predicted to drop due to evaporating of orders in the last quarter of Financial Year 2020, issues of working capital and absence of clearness on the obligations and motivators particularly when exporters from Sri Lanka, Bangladesh and Vietnam get special access. If across the country lockdown proceeds and the circumstance continues, it will affect shopper notion on the higher side, because of conclusion of the market and shopping centre likewise to keeping up social separating, and wellbeing as shown below in Figure 2.

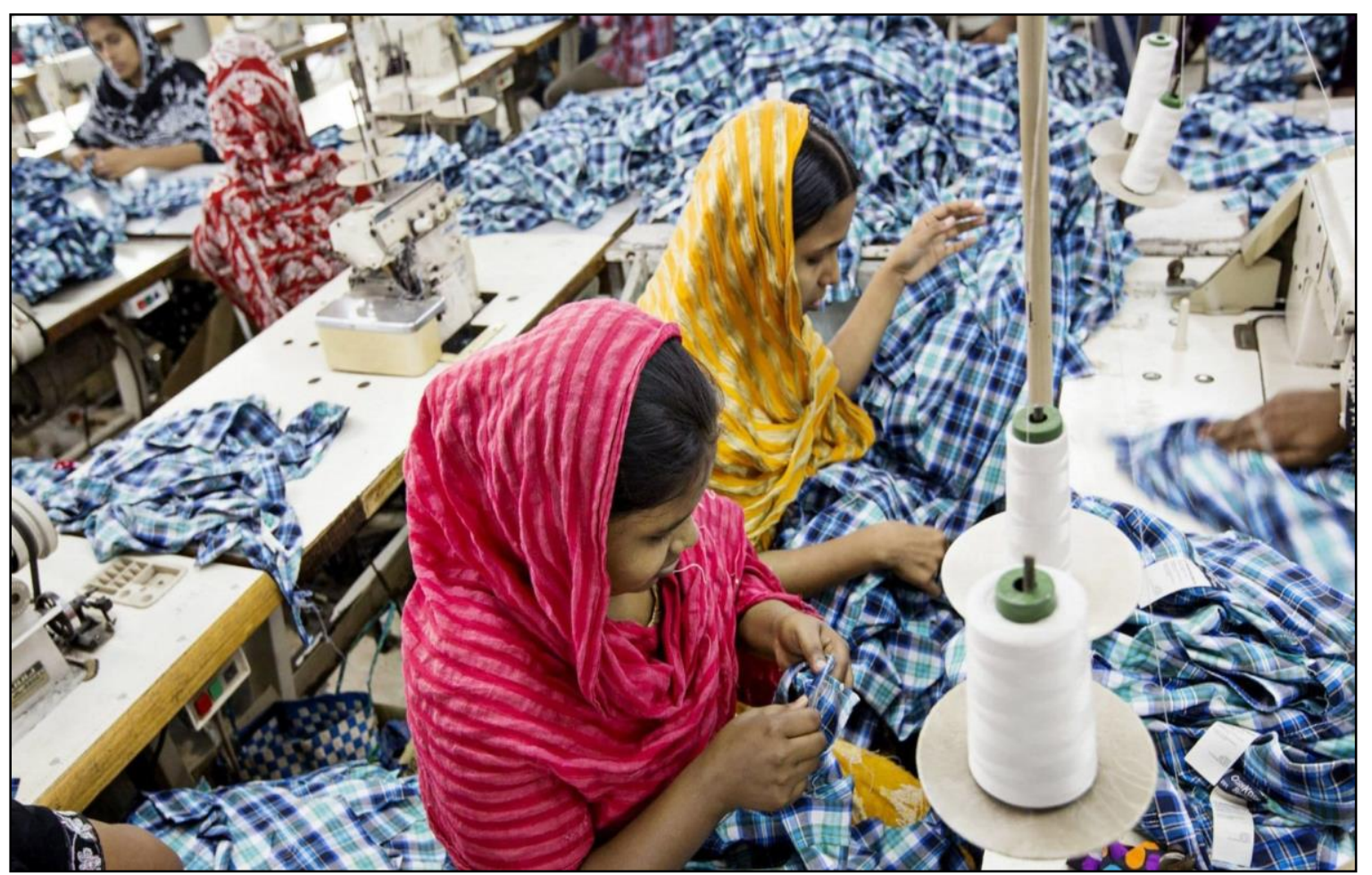

Figure 2: Textile manufacturing process

Source-images bazaar.com

India owns around 2,000 spinning mills with different spindle capacity. Workers in the big strategic business units are always controlled by corporate and these labours reside in labour colonies which are inside the factory premises because the majority of workers are belongs to Bihar, Uttar Pradesh, Orissa and other states. At present they all are job less because of the lockdown and the closing of the factories. Majorly most of the Indian premium apparel are exported to the western countries and that market is collapsed because of the COVID-19.
Additionally, the domestic consumption will also face an impact due to the COVID-19. Not only the domestic consumption but because of the strong impact on the Indian consumption the new stores are stopped to open in the new location and will impact in the sales and also providing the jobs to the jobless. Demand of the newer apparel will show an expected decline in India's textile exports for the next few quarters. Because of the lockdown in China and India also stopped the import from China will create an impact because the man- made fibre which India to import from China is very lower in price but to stop that is expected the rise significantly in 
higher price for some goods in the Indian market like the N-95 mask.

The textile and apparel sector of India, the production is expected to see a decline by 10-12 percent in the quarter of Apr to Jun the 2020.

The cotton prices have been reduced by 3 percent and this is also expected to get more decline in price for the next few months.

Recently, many factory workers have started protesting this and also demanded for the remaining or outstanding wages. Another factor that is to be considered this sector used to export a lot and import cheap raw materials. With trade being at halt, it has now become difficult for the organization to put up with. Though the government has requested all employers not to lay off employees. With this recent threat from CMAI, government is also under pressure.

\section{INTERNATIONAL SCENARIO}

Bangladesh exports lots of its textile and apparels to the Swedish industry. Due to covid19 crisis all the industries in Bangladesh has been put to halt. However, the Swedish government has assured the Bangladesh government that they will not cancel the orders which gave a lot of sigh and relief to the government. It is being estimated that as of 2017 Bangladesh's total export of goods to Sweden stood at near about $700+$ billion US Dollar (3). So that shows that how much this crisis has affected the Bangladesh Textile and apparel industry in terms of revenue generation. However, USA itself has cancelled orders of US $\$ 10$ Million from one of the Bangladeshi manufacturers. Not only this USA have also cancelled orders in Korea also. It is also said and believed that the garment workers in Serbia, Bulgaria, Croatia and Ukraine have been severely hit with all the industries being closed and incurring huge amount of losses.

\section{Automotive and Automotive components business}

The automotive sector was already stressed before the Covid-19 crisis. The situation deteriorated with the onset of the Covid-19 and the continuing phased lockdowns across the country \& it's impact are no different from this. Now we all know that the automotive industry plays a very important role in driving the economy and its growth. As we must not forget that other industries like the "Steel", "Chemical", "Textile" industries are inter-related with each other. One industry getting affected means that all the other four industries will get affected. Not only this the various "Downstream Industries" like repair, mobility and the service sector associated with these industries are all getting highly affected.

The automotive sector has already drastically reduced over the past 12-18 months due to the systematic changes beginning with the money and Taxes, changes to Shared quality, Axle-load changes, Asian nation Stage-IV (BS-IV) to Asian Nation Stage -VI (BS- VI) Conversion, Liquidity Crunch and a lot of. COVID-19 closure has had a continual impact - the business has virtually halted since March twenty fourth. The long run downswing in shopper demand thanks to closure is found to possess a major impact on vehicle manufacturers' profit margins (OEMs) and income.

In response, most industry corporation $m$ 
and development (R\&D) to fund internal operations and to shelve the progress created in different technologies for travel and travel in a pair of locations. Ultimately, some corporations might favour to take a strategic decision out of the non-profit and automotive markets.

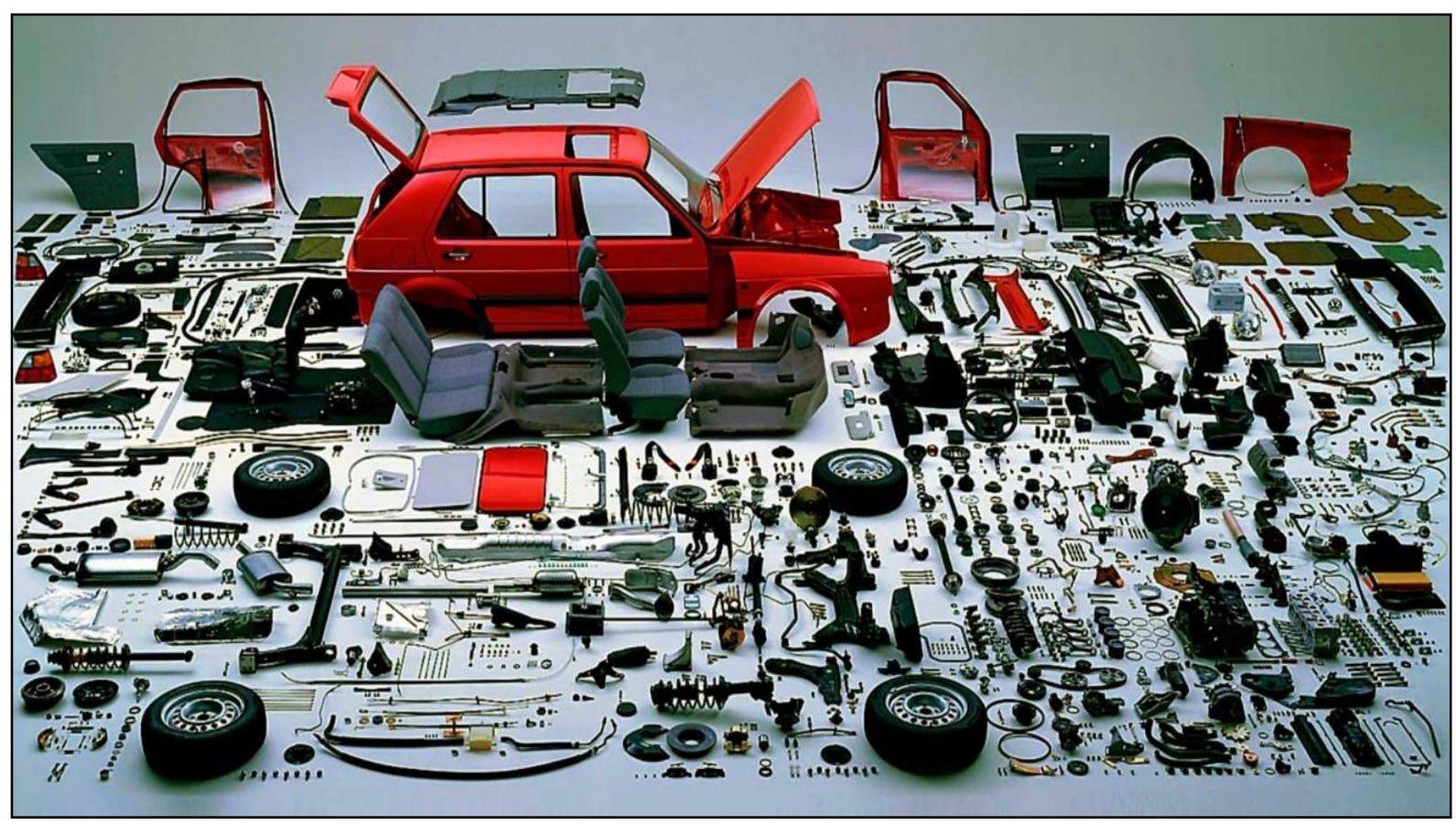

Figure 3: Automotive parts assembly unit

Source-images bazaar.com

Coronavirus pandemic has hit the Indian auto industry hard in two ways. First is the remaining BS-IV stock. Now as we know that the Indian automobile industry was going through a very tough phase and in 2019 its sales stopped as much as $30 \%$, as shown in above Figure 3 . The industry was open for a comeback in the month of March by selling the remaining BS-IV stock by giving additional discounts. However due to the lock down all the dealerships of closed and people are not going out to buy vehicles or the BSIV stock. This has created an anxiety among the dealerships and the dealership association went to Supreme Court asking for an extension which the Supreme Court has provided and after the lockdown 10 days would be given to the dealership across India to sell the remaining BSIV stock.
The second thing is the BS-VI vehicles. A lot of people were hoping that after the new emission norms that are the BSVI will come into play from 1st April 2020, everybody thought that there would be a positive environment and positive sentiments amongst consumers, people would be excited to buy the bs 6 stocks. But now the situation has completely changed due to the coronavirus pandemic. The dealerships are closed; the manufacturing plants across the globe including India are closed. Both BS-IV and BS-VI vehicles are laying either in the plant or indie dealerships. However, the good thing is, the Indian automobile industry has come into act and they have decided to help the Indian government by building the ventilators, making available face masks. Like Mahindra and Maruti has already announced to build ventilators. They 
are also helping them by providing masks for the health industry. There is just hope that this pandemic gets over soon and recovery from this unprecedented situation does not take too long.

A few vehicle producers in India today have declared that they have closed activities of their plants till further notification. That incorporates any semblance of the Maruti Suzuki, Kia Motors, Honda, Hyundai, Volkswagen, Toyota, Tata, Mercedes and Mahindra have chosen to stop their production. Indeed, even vendors and workshops have additionally been arranged to remain shut. As per a survey report released by the "Fitch Solutions", the production of vehicles in the automotive sector in India is likely to contract by nearly $8.3 \%$ in the year 2020 (4). Vehicle dealers were unable to deliver the vehicles at the time of closure, and reportable thirty to forty days of inventory, that can be considerably reduced once the closure of the premises. Additionally, with a BS-VI sale approved from ten days once the cut-off date (and a tenth sale of BS-IV inventory up thereto point), retailers face the large responsibility of ending the BS-IV inventory cheaper to value about 300 Crore (Bureau of Intelligence and Research). OEMs can ought to financially support sales groups, with their own stress despite everything sheets. Reliable cars suppliers bank heavily on migrant staff, that isn't till their job involves a halt once it involves movement down regeneration, resulting in an upshot across the wholesale value vary. Suppliers that area unit experiencing liquidity issues is also laid low with deteriorating market conditions, making disruptions within the entire production atmosphere. a) Providing loans for the people or for the companies with the lower amount of EMI will create a strong impact so that the purchaser can buy another car for them.

b) Passenger vehicles along with the twowheeler and four-wheeler segment: Demand will be reduced for any of the above mentioned because of the decline of the purchasing power along with the job loss and the economic fall.

c) Commercial vehicles segment

i. Because of the shutdown of many of the essential and all the non-essential services, the demand for commercial vehicles is expected to have further decline in sales.

ii. Because of the less earning, the companies are not being able to buy a new car for their company as per the requirement to run their transportation and logistics.

d) The original equipment manufacturers for the Automobiles should delay for any new launches for at least next few quarters or till the improve of the buyer's emotion.

This sector is going to witness following impact in coming days: -

- Engage with customers and vendor network (virtual training designed for sales staff; DIYrelevant videos on customer social media)

- Manage liquidity crunch in the system (financial support for the network with fast moving speed and short-term interest-free relief)

- Contribute to the fight against the epidemic (to support contract workers in the automotive system; production of sanitizers, masks, PPEs in productive plants) 
- Customize post-COVID-19 status (validation with seller request for debit request; short-term schedule skew for spare parts)

- Organize efforts to increase the potential disruption of shared transport and public transit

- Prepare for the boost in post-sales sale (service for wheels and service camps for scheduled repairs)

- Also check for future launches and financial offerings (financial offering schemes)

- Evaluation and reliance on risk-based supply chain (mass production; emergency-based strategies) across the network) (2)

- Configure the Omni-channel sales experience (original sales consultants; online sales and digital publications)

- Hygiene procedure and design changes (sewage / car sealing as part of worksheets and driving tests; unrelated customer journey)
- Explore other revenue options (prioritizing related products and services - accessories, integration services)

- Seize opportunities to integrate activities (partnerships / acquisitions to benefit relationships; new sources of funding)

- Set to change consumer preferences (review merges to focus on situations like other forms of asset ownership)

- Enable digitalisation of consumer touch points (digital end-to-end customer journey across products and services)

- Explore offers around a large-scale local delivery model (product and customer strategy tailored to the growing demand for home delivery)

- Refine processes to be simple and responsive (low-cost business models; analytics use best practices for short-term response strategies)

\section{Along the whole automotive value chain: Four major challenges amid the COVID-19 crisis}

1. Limited Supply of Vahiele Barta Sarsing in Chisa, sucplles arcusd the globe placad production ises in quarartine or ghat then down corrpletely Abs, bagal and trada testricsore, weh as cinaed benters bereased o chortaps of recuired perte end intod dinitulen of supple.

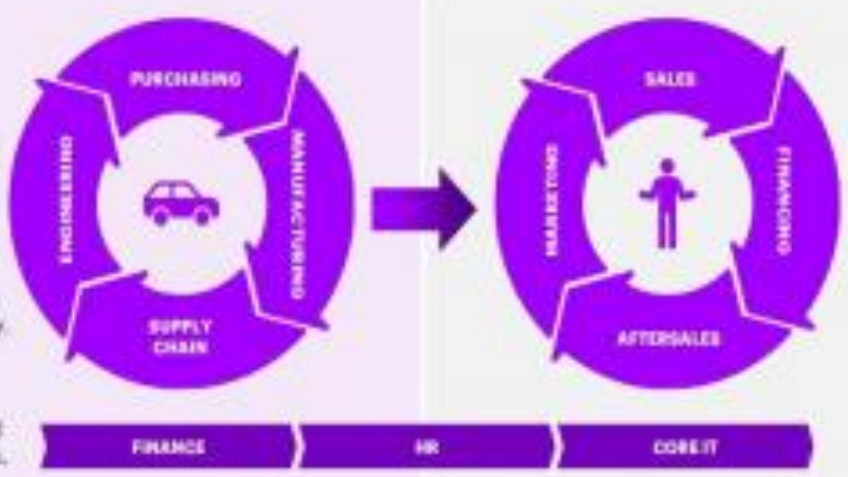

4. Brop in Nev Vehicke Geles to oorrein the ins suchas mplemening curtens dosin tactorien uthen drolershipe and the iesuting destasas of scort time workess, as well at the leve da rectisin, ane libev bo havt to s decrease it sies nunters.

Figure 4: Challenges faced by automotive sector during Covid19 crisis Source-images bazaar.com 
The auto and auto components industry in India is now at a huge loss, with the major component manufactured in China and international boarders being sealed. The future of auto and auto components in India is not looking very good as depicted in Figure 4. The market of the auto and auto components before the breakdown of the pandemic was not very good. And now due to the outbreak of the pandemic the market seems to get worse. There was a huge job loss in this sector before the pandemic and now the situation is unpredictable. Again, as the disposable income of the people are decreasing the chances of revival of this industry is bleak. The industry was expected to rise/ pickup in Diwali, but the chances of it is now dim.

\section{MAJOR IMPACTS FOR THE SUPPLIERS}

\section{Short Term:}

a. Shortage in Component Spare Parts: China's production is slowly coming up but there is a huge disturbance in the supply chain.

b. Reallocation of production parts to Indian suppliers: Due to a huge problem in the supply chain management reallocation is done to the Indian Manufacturers

c. Possibility decrease in export orders due to shut down of USA/Europe trade.

d. Possibility in liquid crunch for suppliers due to increased inventory

\section{Medium Term:}

e. Possible increase in Make in India as global and Indian supply chains mitigate supply risk.

f. Possible decrease in exports as the global players diversify the supply chain.

\section{MAJOR IMPACTS FOR THE OEM}

\section{Short Term:}

g. Decline in production especially BS IV due to supply chain and labour problems due the extension of lock down

h. Delayed availability of BS VI models

i. Potential decline in planned BS IV sales as it was expected to pick up in March 2020.

\section{Medium Term:}

j. Potential extended waiting times for new models due to the problem of the lockdown

k. Increase demand for spares due to temporary labour because of people moving to their hometown

1. Delay in availability of ready for sale and certified vehicles

\section{MAJOR IMPACTS FOR THE DEALERS/DISTRIBUTERS}

\section{Short Terms:}

m. Decline in customer foot falls

n. Liquidity crunch due to blocked working capital in BS IV inventory and loan tightening

o. Drop in automotive demand due to price increase for BS VI transition

\section{Medium Term:}

p. Potential sustained drop in demand due to the consumer confidence differentiation

q. Possibility spike in consumer demand due to social distancing

r. Surge in demand for spares and services due to pent up demand during lockdowns

s. liquidating the standing stock pose a challenge

t. Complexity in receiving appropriate automobile loans- Generally the loans are not being disbursed out for new prospective 
cases, even having higher demand for the same.

But amidst this, there is some ray of hope which can give some relief to the Indian industry. The OEMs can benefit greatly from it, with the international markets being closed and nobody knows when the relations will get better, the advantage of OEMs in great. If they could curb this time of the market, then they could be of great. As the dream of being manufactured in India would also be true. And, the price of the parts and the automobile would also reduce.

Moreover, for the recent tensions in International market, the price of the oil has gone down. And that has been a boon for automobiles the prices of the automobile would decrease. And that would be a blessing for the automobile sector in recent period of recession.

Corporate capacities like fund, HR, IT should work for business coherence and hazard arranging for the time being. Receivables, assortments, consistence and securitization of computerized resources and system will be among other momentary needs. Medium to long haul centre should address overhead decrease, effectiveness improvement, keep up partner correspondence and investigate open doors for robotics and proficiency upliftment. Correspondingly, showcase confronting groups like advertising, deals, administrations should effectively connect with their client to guarantee flexibly, finishing off any on-going arrangements, decrease promoting and re-allot advertising spending plan to advanced media, particularly as customary media like print, TV (aside from news) might be less successful. In the medium to long haul, they should take a shot at their administration contributions; channel development, fixed cost decrease and improving rate of profitability on showcasing spend (5).

The India car industry has just observed troublesome past not many quarters and this pandemic drove lockdown couldn't have been more not well planned. Be that as it may, an arranged and coordinated reaction, both quick and medium to long haul will guarantee a $\mathrm{V}$ shape recuperation. As basic as industry activity will be the help required from government and controllers to catalyse this restoration. All things considered; the present circumstance is a call for activity by every last one in these disturbed occasions.

The employees of many major automobiles were out of job in the financial year of 2019-2020 due to various reasons resulting in huge depression in this market (6). Now the present employees are amidst tension as many of them didn't receive their salary and the everincreasing risk of job loss is striving them hard. Many workers have protested and is protesting. Though the government have requested the employers not to cut down on the employees but until relief package is announced all these promises are void and not much could be said and done.

Be that as it may, the assessed misfortune can be recouped, when creation resumes, and the makers are eager to increase the creation and increment the limit use. The residential car segment is as of now experiencing a negative stage starting at now with extreme underutilisation of limit because of moderate interest during the most recent year. Presently, the coronavirus pandemic has constrained the automakers to stop creation at 
their offices and power their non-producing representatives to telecommute. Starting at now, the OEMs have ended the creation at their chose offices where the state government have given requests for the total shutdown. In any case, seeing the size of the effect and exponential ascent in the instances of coronavirus over the most recent two days, a few specialists accept that the auto part might be going towards a 100 percent shutdown.

Published by ET, The Indian bionetwork may take stimulus from Chinese OEMs to fight the slowdown. A few of the troupes such as Volkswagen, SAIC, Nissan and BMW in China have twisted to the online sale of cars, using VR and live programs to rouse transactions.

Following measures pre and post lockdowns:

- Vigorously donate to belligerent the epidemic (sustenance bond labours in the motorized ecosystem; production of sterilizers, masks, PPEs)

- Design well for the post-COVID-19 state Post lockdown:

- $\quad$ Fix for the barb in after-sales

- Re-assess forthcoming promotions and funding

- Measure and de-risk source chain dependences

- Espouse digitalization of customer touch points

The effect of COVID on the economy and car industry could differ contingent upon power, length and spread of the episode. Therefore, the economy may observer a recuperation that is $\mathrm{V}$ shape - Quick recuperation, U shape - Impacting entire of 2020 or L shape - year and a half of downturn (7).

Having guaranteed a quick reaction to the episode and lockdown, Indian car organizations should distinguish where to act rapidly and unequivocally both temporarily and long haul. While transient need is kept up liquidity and proficiency, mid- term need ought to be to re-establish gainful consistent activities while in the drawn-out associations may on a very basic level need to audit their methodology and working model.

Various pieces of the association will have various tasks to carry out. For instance, the system group should arrangement a war room and attempt situation arranging temporarily and consider fine tuning their procedures and reexamining their vital arrangement and plan of action in the medium to long haul.

Though 2021, the share market saw a good rise and is expected to bring in good news for this sector. But much of these speculations could be put to test when the lockdown lifts and people resume their jobs and disposable income again increases. Until then nothing could be said and done concretely. It is expected the Government would announce relief package and no more job losses would be there. And this industry is expected to bloom again (8).

\section{Managerial implications and advisory}

- Retain and Reconnect with current consumer base

- Shift of Disrupting Engagement to Empathetic and compassionate Engagement

- Focus into formulation of mediums of Trust, platform influences offline and online

- Hyper local Connect physically

- Collaborations will be imperious to grow and develop

- Lean strategy adoption

- Transference from customer focused to human centric communication. 


\section{CONCLUSIONS}

To conclude, the paper clearly traced and highlighted that there is uncertainty amongst every group of consumers. Covid19 has set in a novel way of living for altogether. It also elaborates on the resistance, challenges and the evolving consumers' sentiments. The risk is that extended delay of brands in getting out and activating may open prospects for those who were superior placed during pandemic but not long capitalized in these markets.

\section{ACKNOWLEDGEMENT}

The author wishes to acknowledge the constant support \& motivation of Fr. Dr. John Felix Raj, Vice-Chancellor of St Xavier's University, Kolkata. Dr. Islam also wishes to thank Dr. Manodip Ray Chaudhuri, Dean Xavier Business School for guiding \& providing valuable insights towards academic enrichment.

\section{CONFLICT OF INTEREST}

There is no conflict of interest in this present research paper. This research work is not a part of any other studies and it is our original work.

\section{REFERENCES}

1. Jan Saahas Survey. 2020. Lockdown is only the beginning of misery for India's migrant labourers. Quartz.com. https://qz.com/india/183 3814/coronavirus-lockdown-hits-india-migrantworkers-pay-food-supply/

2. The Economist. 2020, February 15. The new coronavirus could have a lasting impact on global supply

chains. https://www.economist.com/internationa l/2020/02/15/the-new-coronavirus-could-havea-lasting-impact-on-global-supplychains?cid1=cust/ednew/n/bl/n/2020/02/29n/ owned/n/n/nwl/n/n/AP/415278/n

3. https://economictimes.indiatimes.com/markets/ stocks/news/coronavirus-its-impact-on-varioussectors/chemicals/slideshow/74490807.cms

4. https://www.moneycontrol.com/news/photos/in dia/covid-19-impact-on-india-multiple-sectorsaffected-in-six-months-of-lockdown5882081.html

5. https://www.statista.com/statistics/1107798/in dia-estimated-economic-impact-of-coronavirusby-sector/

6. BAM and Jothikumar R. "Social economic impact of COVID-19 outbreak in India", International Journal of Pervasive Computing and Communications. 2020. Vol. 16 No. 4, pp. 309-319.

7. Oswal M. 2020, March 26. With 75\% economy under lockdown, analysts see sharp fall in GDP. Business Standard. https://www.businessstandard.com/article/economy-policy/with-75economy-under-lockdown-analysts-see-sharpfall-in-gdp-120032600231_1.html.

8. Radhika Pandey AP. 2020. Covid-19 and MSMEs: The 'identification' problem. Ideas for India for More Evidence Based Policy. https://www.ideasforindia.in/topics/macroecono mics/covid-19-and-the-msme-sector-theidentification-problem.html. 